A - preparing concepts

$\mathrm{B}$ - formulating methods

$\mathrm{C}-$ conducting research

$\mathrm{D}$ - processing results

$\mathrm{E}$ - interpretation and conclusions

$\mathrm{F}$ - editing the final version

\section{Effects of subtalar joint hipermobility on load-bearing capability of the musculoskeletal system of the foot during free gait - literature review}

\section{Wpływ nadruchomości stawu podskokowego na obciążenie układu mięśniowo-szkieletowego stopy podczas chodu swobodnego - przegląd piśmiennictwa}

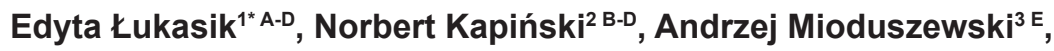 \\ Michał Wychowański ${ }^{1 \mathrm{E}}$, Andrzej Wit ${ }^{1 \mathrm{~A}, \mathrm{E}-\mathrm{F}}$ \\ ${ }^{1}$ Faculty of Rehabilitation, Jozef Pilsudski University of Physical Education \\ in Warsaw, Poland; Wydiał Rehabilitacji, Akademia Wychowania Fizycznego \\ Józefa Piłsudskiego w Warszawie \\ ${ }^{2}$ Interdisciplinary Centre for Mathematical and Computational Modelling \\ at Warsaw University; Interdyscyplinarne Centrum Modelowania Matematycznego \\ i Komputerowego Uniwersytetu Warszawskiego \\ ${ }^{3}$ Centre for Specialised Surgery ORTOPEDIKA in Warsaw; Centrum Chirurgii \\ Specjalistycznej ORTOPEDIKA w Warszawie;
}

\section{Abstract}

Flat foot is caused by subtalar joint hypermobility which leads to changes in foot mechanics while walking. It results in increased load of the musculoskeletal system of the foot. It is proved by the literature which presents flat foot as an etiological factor responsible for numerous overuse injuries in this region. In particular, they concern the structures which support the longitudinal arch of the foot, i.e. Achilles tendon, tendons of tibialis posterior muscle, plantar fascia, sesamoid bones, hallux, metatarsal head and metatarsal bones. Due to the fact that foot loads and mechanics change during different gait phases, the magnitude of forces affecting particular tendons and ligaments also varies at its specific phases. Therefore, it is important that the findings of the latest studies on flat foot be collected in order to develop appropriate programmes of functional rehabilitation of the indicated deformity as well as therapeutic programmes for overuse injuries. Although this deformity and its consequences are a common problem, the foot still remains an unexplored area at the level of kinematics and kinetics. In particular, it is necessary to conduct research regarding correlations between the foot structure and its functions. It will be possible to broaden the knowledge in this field owing to the development or identification of the mathematical foot model taking into account common kinesiological problems with lower limbs that stem from flat foot.

Key words: $\quad$ musculoskeletal system, foot deformities, flat foot, foot diseases, gait

email: edyta.lukasik@op.pl

The research was financed from statutory resources - Young Scientists; Projects

DM-41 financed by the Ministry of Science and Higher Education

Źródła wsparcia finansowego: Dotacja Statutowa - Projekty Młodych Naukowców

DM-41 finansowana przez polskie Ministerstwo Nauki i Szkolnictwa Wyższego 
Słowa kluczowe:

\section{Streszczenie}

Stopa płasko-koślawa powstaje w wyniku nadruchomości stawu podskokowego, co doprowadza do zmiany mechaniki stopy podczas chodu. Konsekwencją tego jest zwiększone obciążenie układu mięśniowo-szkieletowego stopy. Potwierdzone jest to przez literaturę, w której stopa płasko-koślawa przejawia się jako czynnik etiologiczny wielu urazów przeciążeniowych tego obszaru. W szczególności dotyczą one struktur pełniących funkcję podporową sklepienia podłużnego stopy tj. ścięgna Achillesa, ścięgna mięśnia piszczelowego tylnego, rozcięgna podeszwowego, trzeszczek, palucha, głów kości śródstopia i kości śródstopia. Ze względu na to, obciążenia i kształt stopy zmieniają się podczas poszczególnych faz chodu, to również wielkości sił działających na poszczególne ścięgna i więzadła jest również zróżnicowane w jego poszczególnych etapach. Dlatego istotne jest zebranie opublikowanych wyników najnowszych badań dotyczących funkcjonowania stopy płasko-koślawej, aby stworzyć podstawy właściwego programowania rehabilitacji wskazanej wady stopy oraz programów terapii poszczególnych urazów ze szczególnym uwzględnieniem profilaktyki przeciążeń w obrębie kończyny dolnej. Pomimo dużego rozpowszechnienia stopy płasko-koślawej we współczesnych społeczeństwach, jak i następstw wynikających z tej wady, stopa wciąż jest niezbadanym obszarem z punktu widzenia jej kinetyki. W szczególności konieczne jest podjęcie badań w zakresie zależność pomiędzy budową a funkcjonowaniem stopy. Poszerzenie wiedzy w tym zakresie będzie możliwe dzięki opracowaniu i identyfikacji adekwatnego modelu matematycznego opisującego funkcjonowanie stopy z uwzględnieniem znanych problemów kinezjologicznych kończyn dolnych wynikających z dysfunkcji stopy płasko-koślawej.

system mięśniowo-szkieletowy, deformacje stopy, stopa płasko-koślawa, deformacje stopy, wprowadzenie do chodu

\section{Introduction}

Flat foot is the most common foot defect both in children and adults [1-3]. Nevertheless, the collapsed longitudinal arch is only a consequence of changes in the musculoskeletal system brought about by subtalar joint hypermobility, which is the immediate cause of this deformity [4]. A detailed analysis of this pathology is necessary to respond to the question "why?" in reference to foot overuse injuries. The explanation of this phenomenon makes it possible to develop an appropriate rehabilitation programme for flat foot and to modify therapeutic programmes for overuse injuries.

In the study, an attempt was made to gather results of the latest investigations on identification of kinesiological characteristics of the subtalar joint, pathomechanics of its hypermobility and its influence on the load of particular foot structures while walking. Functional anatomy of flat foot requires further research since the correlations between foot structure and its functions have not been thoroughly explored [5]. The analysis of flat foot biomechanics requires the cooperation within an interdisciplinary research team and the application of advanced technologies which can facilitate investigating particular causes of flat foot occurrence. A 3-D movement analysis combined with concurrent measurement of ground reaction forces and electromyography of particular muscles in a free gait is a highly effective tool used to measure and identify flat foot dynamics. The obtained characteristics of a pathological gait enable researchers to analyse foot load analysis with the use of mathematical modelling methods, which, in turn, allows for a quantitative analysis of foot functions, identification of overload spots in the foot region and implementation of appropriate therapeutic strategies [6].

\section{Subtalar joint and its functions}

The subtalar joint is a posterior part of the inferior ankle joint - posterior ankle joint. It is situated between the talus and the calcaneus (it connects the articular calcaneal posterior surface of the talus and the articular tarsal posterior surface of the calcaneal bone) [7].

It is a spot where pronation and supination take place, around the rotational axis running askew 
from the inferior-lateral part of the calcaneal bone to the superior-medial part of the tarsal bone [7,8].

Due to the lack of joint surface congruence, the subtalar joint shows features of high stability and requires significant support of the ligament system [9]. Its most efficient inactive stabilisers include plantar calcaneonavicular ligament, plantar fascia, plantar ligaments (long plantar and plantar calcaneocuboid ligaments), talocalcaneal interosseous ligaments and joint capsules of talonavicular and calcaneonavicular joints [7]. The crucial points in terms of subtalar joint stabilisation also result from the fact that no muscle which could provide dynamic stabilisation is attached to the tarsal bone [9]. Other factors include an askew position of the articular surface which is inclined towards the medial direction and the transverse position of the calcaneal bone in relation to the long axis of the tibial bone which is directed towards its medial region. Thus, when the body load is transferred onto the tarsal bone, it causes natural pronation in the subtalar joint [10]. Therefore, the bone shape which limits the range of pronation is crucial for its stability. Movement restriction means that the lateral process of the tarsal bone touches the floor of the tarsal sinus of the calcaneal bone. As a result, further movement is impossible $[4,8,11]$.

The subtalar joint plays an important role in terms of foot function performance during gait. It includes shock absorption, stability or a movement process. It can be concluded that its mobility influences the mobility of all other foot joints [8]. It is based on e.g. its synergic motion with the transverse tarsal joint [10]. The subtalar joint consists of talonavicular and calcaneocuboid joints which function as a single joint. It is in this joint that tarsal dorsiflexion and plantar flexion take place which, in turn, significantly influences the shape of the foot arch and intratarsal stability. When pronation in the subtalar joint occurs, axes of the joints which are part of the transverse tarsal joint are in a parallel position in relation to each other as a result of changes in the position of the tarsal and calcaneal bones, which enables tarsal dorsiflexion. It results in high elasticity of the tarsus and metatarsus, which, under loading conditions, manifests itself through physiological flattening of the longitudinal arch of the foot. During the subtalar joint supination, joint axes that form the transverse tarsal joint are in an askew position in relation to each other. It causes plantar flexion in the tarsal region, thus leading to a maximum reduction in its mobility, "blocking" the transverse tarsal joint as well as the reconstruction of the foot arch and provision of high metatarsal stability [12]. The change in the mutual position of the tarsal and navicular bone, which influences the position of the $1^{\text {st }}$ metatarsal bone (in the plantar direction), is of crucial importance. The change in the bone position is caused by the peroneus longus activity. It influences the forefoot stability in the stance phase $[10,13]$.

Synergic activity of the subtalar joint and the transverse tarsal joint allows for effective performance of the foot in the following way [10]:

- Subtalar joint pronation and tarsal dorsiflexion are responsible for shock absorption (the foot is elastic),

- Subtalar joint supination and plantar flexion of the tarsus are responsible for intratarsal stability (foot stabilisation), which provides proper conditions for propulsion performance.

\section{Subtalar joint hypermobility}

Hypermobility (exceeding the range of motion) of the subtalar joint occurs when the foot is loaded with body weight $[4,8,14]$ and structures responsible for passive stabilisation of the joint exhibit decreased performance capacity $[15,16]$.

Subtalar joint hypermobility manifests itself through increased internal rotation of the talus during body load transfer, with its concurrent excessive movement in relation to the calcaneal bone in the calcaneal-medial-anterior direction [8]. As a consequence, the lateral process of the talus cannot touch the tarsal sinus and the terminal bone resistance is delayed. Furthermore, it causes the dislocation of the superior part of the subtalar joint axis, which runs through the neck of the tibia in the calcaneal-medial direction [11]. The above phenomena result in increased pronation manifested through excessive abduction of the hindfoot $[4,11]$.

Currently, radiological diagnostics is applied in clinical settings to diagnose subtalar joint hypermobility. On the basis of lateral projection, it is possible to evaluate the position of the tarsal bone in relation to the calcaneal bone and the space between them (tarsal sinus) [14,17]. In physiological conditions, when the lateral process of the tarsal bone rests on the floor of the tarsal sinus, some space between both bones can be seen from the lateral side. The space is known as "open tarsal sinus" [8]. 
If the tarsal bone slides from the calcaneal bone, this space is not present. In that case, the space is called "closed tarsal sinus" and it is interpreted as subtalar joint hypermobility $[8,11]$.

\section{Effects of subtalar joint hypermobility on gait}

Studies carried out so far have shown that individuals with flat foot demonstrate an increased range of pronation, and its duration is extended in the support phase of free gait $[17,18,19]$. As a consequence, it affects foot-related mechanics in particular stages of the gait [8].

\section{Initial Contact (0-2\% of the gait cycle)}

When the heal touches the ground, the superior ankle joint is in its natural position and the subtalar joint is in supination [7]. The literature does not indicate any consequences of subtalar joint hypermobility.

\section{Loading Response (2-10\% of the gait cycle)}

In physiological conditions, plantar flexion occurs in the superior ankle joint. The foot is placed flatly on the ground and downward force observed when accepting the load $(60 \%$ of the body mass in 0.02 s.) is significantly equalised in forward momentum. Due to the transverse position of the calcaneal bone in relation to the long axis of the tibia, body weight shifted to the talus produces natural pronation in the subtalar joint, whereas dorsiflexion in the transverse tarsal joint absorbs shock impacts. Thanks to heel rocker mechanisms, movement progression occurs as well $[7,10]$.

In individuals with flat foot, an increased range of pronation starts from this phase [17-19]. Pathological hypermobility in an indicated direction is brought about by weakened structures which passively stabilise the subtalar joint when high stabilisation is needed, i.e. when body weight falls on the medial part of the calcaneal bone, which leads to a dislocation of the talus in the plantarcaudal direction [11].

\section{Mid Stance (10-30\% of the gait cycle)}

In physiological conditions, when the foot is fully loaded, the range of dorsiflexion in the superior ankle joint is gradually increased for the purpose of movement progression. Pronation is continued in the subtalar joint. It reaches the highest value at the beginning of each phase and then it gradually decreases [17-19]. As a result, higher mobility is maintained in all the foot joints as it influences the transverse tarsal joint, which is positioned in dorsiflexion (it is not blocked). It ensures foot elasticity and allows it to absorb shocks effectively. At the end of the Mid Stance phase, the whole body weight is moved to the lateral part of the foot, which leads to supination in the subtalar joint $[7,10]$.

In the case of flat foot, when accepting the entire body weight, the talus continues excessive internal rotation and dislocation in the plantar-medial direction in relation to the calcaneal bone. As a result, the lateral process of the talus cannot touch the floor of the tarsal sinus [4,11]. Consequently, it leads to an increase in the range of pronation and in its duration [17-19].

Excessive movement of the head of the talus in the calcaneal-medial direction extends the plantar calcaneal-navicular ligament [14,20], which supports it directly from the plantar side [20].

Together with the dislocation of the talus, there occurs a change in the position of the subtalar joint, which follows the head of the talus (through which it goes) in the medial-plantar direction [11]. It results in increased external pronation which is resisted by internal supination generated by the triceps surae [21]. As a consequence, the Achilles' tendon is exposed to excessive forces [20].

The increased mobility range leads to excessive dorsiflexion in the transverse tarsal joint [21], which results in the flattening of the longitudinal arch [8]. Consequently, the posterior tibial muscle, which is the main dynamic stabiliser of the transverse tarsal joint and foot arch, carries through its tendon the excessive load during the entire mid stance $[1,14-$ 16]. Therefore, it can be concluded that it cannot effectively pull the navicular bone in the plantar direction and backwards under the head of the talus, which is too collapsed [8,9]. The inefficiency of this mechanism leads to the lack of prominence of the longitudinal arch $[1,2,15,16]$.

\section{Terminal Stance (30-50\% of the gait cycle)}

In physiological conditions, the heel is detached from the ground in the terminal stance phase. It is accompanied by blocking of the superior joint ankle in maximal dorsiflexion caused by eccentric work of the soleus muscle and posterior tibial muscle. The rotation axis during this phase runs through the heads of the metatarsal bones $[7,10]$. In turn, 
preliminary passive supination takes place in the subtalar joint (as a result of body weight shift to the lateral part of the foot in the previous phase), which allows for plantar flexion of the transverse tarsal joint, thus blocking it and causing the stiffness of the foot [22].

Plantar flexion of the "first radius" in the talonavicular joint is an essential element of this phase. It is additionally supported with the work of the peroneus longus, which lowers the $1^{\text {st }}$ bone of the metatarsus by drawing it in the plantar direction. This allows the head of the $1^{\text {st }}$ bone of the metatarsus to have a stable contact with the ground. It also provides conditions for the stable forefoot to be the only region of support when body weight is transferred to its medial part. The body weight vector is moved in the direction of the $1^{\text {st }}$ radius during the rocker mechanism (the terminal position of the CoP is between the $1^{\text {st }}$ and $2^{\text {nd }}$ metatarsalphalangeal joint). The indicated mechanism contributes to effective performance of movement progression $[4,10,13]$.

Plantar fascia is an additional structure which supports the passive stabilisation of the foot arch at the end of the terminal stance phase. It runs from the medial part of the calcaneal tuber to the proximal phalanges of the five toes. It operates on the basis of "the wheel and axle mechanism". It means that only when it reaches at least $30^{\circ}$ of the flexion in the metatarsal-phalangeal joints, does it stretch like a bowstring that connects the two ends of the longitudinal arch of the foot [11].

In the case of flat foot, pronation of the subtalar joint takes place at the beginning of the terminal stance phase, while a reduced range of supination occurs in the later phase [17-19,22,23]. It leads to a difficulty in performing plantar flexion in the transverse tarsal joint, which has three consequences [21]. Firstly, this situation poses a problem related to blocking the transverse tarsal joint, as it obstructs metatarsal stabilisation when the foot should function as a stiff arm of the lever in order to provide conditions for detaching the heel from the ground and performing effective movement progression $[14,22,23]$. As a result, compensatory activity of the soleus muscle can be noted. Through increasing the force, it draws the calcaneal bone towards supination in order to block the transverse tarsal joint in an active manner [8,21]. This, again, causes the shift of higher loads through the Achilles tendon $[4,20]$, which is shortened in individuals with flat foot due to the position of the calcaneal tuber. It results in its decreased elasticity and strength [4]. It also lowers propulsion efficiency, thus decreasing movement-related function of the foot [14]. The second consequence concerns the problem of hypermobility of the "first radius" positioned in dorsiflexion $[13,22,23]$. As a result, the head of the $1^{\text {st }}$ metatarsal bone does not provide stable support on the ground and, at the same time, it decreases forefoot stabilisation as the only supporting surface $[22,23]$. It leads to the shift of the load from the metatarsal region to the head of the $2^{\text {nd }}$ metatarsal bone, which is incapable of bearing such weight. As a consequence, metatarsalgia develops in this region $[5,13,23,24]$. Numerous studies are conducted to confirm or reject the hypothesis according to which hypermobility of the "first radius" results in the bunion occurrence [13]. The third consequence is connected with "inefficiency of the wheel and axle mechanism" caused by hypermobility of the "first radius". It leads to the lack of effective structure tension in the plantar surface (including plantar fascia), which, in physiological conditions, blocks the metatarsal joints during propulsion [14].

Pre Swing (50-60\% of the gait cycle)

In physiological conditions, dorsiflexion in the superior ankle joint and supination in the subtalar joint occur $[7,10]$. Detachment from the ground takes places through the hallux [10].

In persons with flat feet, significant forefoot pronation [22,23] and a decrease in its adduction can be noted [21]. It stems from a decreased range of supination in the subtalar joint. However, the literature does not indicate the damaging effects of this phase on the musculoskeletal system of the foot. It may result from the fact that this phase includes two points of support.

\section{Overuse injuries}

The structures of soft tissues, e.g. the plantar calcaneal ligament, Achilles tendon, the tendon of the posterior tibial muscle, plantar fascia (which function as support), are to minimise pathological tarsal mobility in flat foot. This leads to excessive chronic overload which surpasses their physiological strength [8]. As a consequence, there occur injuries which, in turn, lead to degenerative and negative organisational changes in their structure 
[4,13,20,25-28]. Clinical symptoms include pain, which lowers life quality, hinders activities of daily living and compels patients to have a break or resign from performing certain sports (both sports for all and professional sports) [29]. The studies also show that the collapsed foot arch is a predisposition to extending reaction time of the peroneus longus when sudden inversion occurs, which results in torsional injuries of the ankle joint [30,31].

\section{Flatfoot epidemiology}

Talking aboutflatfoot epidemiology, it is necessary to highlight the fact that the problem occurs is in the field of its diagnostics. It should combine the availability of examinations, low harmfulness to the patient and a high level of objectivity of the obtained results [17-19]. Hence the variety of the applied methods in particular studies and, consequently, in the findings concerning the prevalence of flat foot.

Studies conducted on big populations have found that flat foot occurs in $2.2 \%-6.6 \%$ of adults [1-3]. However, it is not possible to generalise the findings due to the fact that the occurrence of the deformity is influenced by factors such as BMI, type of work or a place of residence [3]. In turn, the literature indicates that the problems within the musculoskeletal system of the foot can be observed in $30 \%$ of middle-aged and elderly patients [25,32], which confirms a large scale of the condition.

\section{Future research}

In the literature of the subject, flat foot is presented as an etiological factor in numerous overuse injuries, i.e. injuries of Achilles tendon, posterior tibial muscle, plantar fascia, sesamoid bones, hallux, head of the metatarsal bones and metatarsal bones. Research conducted so far as well as clinical practice among patients with radiologically diagnosed subtalar joint hypermobility have shown the correlation between the dynamic function of the foot and overuse injuries in its region. Simultaneously, attention is drawn to the fact that it is still an unexplored foot-related kinematic and kinetic correlation [26].

In order to define the sizes ofmechanical parameters in the subtalar joint during gait, it is necessary to develop or identify the mathematical foot model consistent with the described anatomical problems. Currently proposed advanced solutions are based on the structure of the system consisting of various numbers of stiff blocks (segments) connected with each other by means of mathematical dependences which model the joint function. Examples of multisegmental models can be found in the literature [33-36]. The most advanced models are made of $8,9,11$ or even 26 segments, which constitutes an illustration of all the foot bones [6,37-40].

Further research will focus on defining the optimal model and its potential modifications that are necessary to provide the best possible evaluation of the implications linked to the problem of flat foot. The research should aim to identify the number of degrees of freedom in the model (particularly in the region of the subtalar joint, where the pathological foot demonstrates the translation of the talus bone in relation to the calcaneal bone), to define dynamic parameters that exert a significant influence on the force distribution in the system as well as to develop or to adapt an adequate measuring protocol which would enable researchers to calculate all model parameters with as little a margin of error as possible.

\section{References}

1. Kohls-Gatzoulis J, Woods B, Angel JC, Singh D. The prevalence of symptomatic posterior tibialis tendon dysfunction in women over 40 in England. Foot Ankle Surg. 2009;15(2):75-81.

2. Kołodziej Ł, Napiontek M, Kazimierczak A. Wiedza uczestników V Kongresu Polskiego Towarzystwa Stopy i Stawu Skokowo-Goleniowego na temat diagnostyki i leczenia stóp płasko-koślawych w następstwie niewydolności ścięgna mięśnia piszczelowego tylnego. Ortopedia Traumatologia Rehabilitacja. 2013;6(6):641-8.

3. Shibuya N, Jupiter DC, Cliliberti LJ, Van Buren V, La Fontaine J. Characteristics of Adult Flatfoot in the United States. J Foot Ankle Surg. 2010 Jul-Aug;49(4):363-8.

4. Graham ME, Jawrani NT, Chikka A. Extraosseous Talotarsal Stabilization Using HyProCure In Adults: A 5-years Retrospective Follow-up. J Foot Ankle Surg. 2012 Jan-Feb;51(1):23-9. 
5. O'Brien DL, Tyndyk M. Effect of Arch type and Body Mass Index on plantar pressure distribution during stance phase of gait. Acta of Bioeng Biomech. 2014;16(2):131-5.

6. Long JT, Wang M, Winters JM, Harris GF. A multisegmental foot model with bone-based referencing: sensitivity to radiographic input parameters. Conf Proc IEEE Eng Med Biol Soc. 2008:879-82.

7. Jastifer JR, Gustafson PA. The Subtalar Joint: biomechanics and functional representations in the literature. Foot (Edinb). 2014 Dec;24(4):203-9.

8. Graham ME, Jawrani NT. Extraosseous Talotarsal Stabilization Devices: A New Classification System. J Foot Ankle Surg. 2012 Spe-Oct;51(5):613-9.

9. Mittlmeier T, Wichelhaus A. Subtalar joint instability. Eur J Emerg Surg. 2015 Dec;41(6):623-9.

10. Piazza JS. Mechanics of the subtalar joint and its function during walking. Foot Ankle Clin. 2005 Sep;10(3):425-42.

11. Kirby KA. Understanding The Biomechanics Of Subtalar Joint Arthroereisis. Podiatry Today. 2011 Apr;24(4):36-45.

12. Okita N, Meyers SA, Challis JH, Sharkey NA. Midtarsal joint locking: new perspectives on an old paradigm. J Orthop Res. 2014 Jan;32(1):110-5.

13. Doty JF, Coughlin MJ. Hallux valgus and hypermobility of the first ray: facts and fiction. Int Orthop. 2013 Sep;37(9):1655-60.

14. Toullec E. Adult flatfoot. Orthop Traumatol Surg Res. 2015 Feb:101(1 Suppl):S11-7.

15. Hintermann B, Knupp M. Injuries and dysfunction of the posterior tibial tendon. Orthopade. 2010 Dec;39(12):1148-57.

16. Vulcano E, Deland JT, Ellis SJ. Approach and treatment of the adult acquired flatfoot deformity? Curr Rev in Musculoskeletal Med. 2013 Dec;6(4): 294-303.

17. Levinger P, Murley GS, Barton CJ, Cotchett MP, McSweeney SR, Menz HB. A comparison of foot kinematics in people with normal and flat arched feet using the Oxford Foot Model. Gait \& Posture. 2010 Oct;32(4):519-23.

18. Buldt AK, Levinger P, Murley GS, Menz HB, Nester CJ, Landorf KB. Foot posture is associated with kinematics of the foot during gait: A comparison of normal, planus and cavus feet. Gait Posture. 2015 Jun;42(1):42-8.

19. Buldt AK, Murley GS, Butterworth P, Levinger P, Menz HB, Landorf KB. The relationship between foot posture and lower limb kinematics during walking: A systematic review. Gait Posture. 2013 Jul;38(3):363-72.

20. Cromeens BP, Kirchhoff CA, Patterson RM, Motley T, Stewart D, Fisher C et al. An attachment-based description of the medial collateral and spring ligament complex. Foot Ankle Int. 2015 Jun;36(6):710-21.

21. Lee JE, Park GH, Lee YS, Kim MK. A comparison of muscle activities in the lower extremity between flat and normal feet during one-leg standing. J Phys Ther Sci. 2013 Sep;25(9):1059-61.

22. Chimenti RL, Tome J, Hillin CD, Flemister AS, Houck J. Adult-Acquired Flatfoot Deformity and Age-Related Differences in Foot and Ankle Kinematics During the Single-Limb Heel-Rise Test. J Orthop Sports Phys Ther. 2014 Apr;44(4):283-90.

23. Kim MK, Lee YS. Kinematics analysis of the lower extremities of subjects with flat feet at different gait speed. J Phys Ther Sci. 2013 May:25(5):531-3.

24. Lorkowski J, Grzegorowska O, Kotela I. Zastosowanie badania pedobarograficznego do oceny biomechaniki stopy i stawu skokowo-goleniowego u osób dorosłych - doświadczenia własne. Ortopedia Traumatologia Rehabilitacja. 2015;2(6):207-13.

25. Dowling GJ, Murley GS, Munteanu SE, Smith MM, Neal BS, Griffiths IB, Barton CJ et al. Dynamic foot function as a risk factor for lower limb overuse injury: a systematic review. J Foot Ankle Res. 2014 Dec;7(1):53.

26. Neal BS, Griffiths IB, Dowling GJ, Murley GS, Munteanu SE, Franettovich Smith MM, Collins NJ at el. Foot posture as risk factor for lower limb overuse injury: a systematic review and meta-analysis. J Foot Ankle Res. 2014 Dec.19;7(1):55.

27. Nguyen AD, Shultz SJ, Shmitz RJ, Luecht RM, Perrin DH. A preliminary multifactorial approach describing the relationships among lower extremity alignment, hip muscle activation and lower extremity joint excursion. J Athl Train. 2011 MayJun;46(3):246-56.

28. Sobhani S, Dekker R, Postema K, Dijkstra PU. Epidemiology of ankle and foot overuse injuries in sports: A systematic review. Scand J Med Sci in Sports. 2013 Dec;23(6):669-86.

29. Thomas MJ, Roddy E, Zhang W, Menz HB, Hannan MT, Peat GM. The population prevalence of foot and ankle pain in middle and old age: a systematic review. Pain. 2011 Dec;152(12):2870-80.

30. Deynyer JR, Hewitt NL, Mitchell AC. Foot Structure and Muscle Reaction Time to a Simulated Ankle Sprain. J Athl Train. 2013 May-Jun;48(3):326-30.

31. Drzal-Grabiec J, Rachwał M, Trzaskoma Z, Rykała J, Podgórska-Bednarz J, Cichocka I. et al The foot deformity versus postural control in females aged over 65 years. Acta Bioeng Biomech. 2014;16(4):75-82.

32. Durrant B, Chockalingam N, Richards P, Morriss-Roberts Ch. Posterior Tibial Tendon Dysfunction: What does the single heel raise test mean in assessment? The Foot and Ankle Online Journal. 2015 Jun;8(2):6.

33. Church Ch, Henley J, Coleman S, Lennon N, Angeli T, Miller F. Multi-segment kinematics of the planovalgus foot. Gait Posture. 2006 Dec;24(2 Suppl):S238-9.

34. Jenkyn TR, Anas K, Nichol A. Foot Segment Kinematics During Normal Walking Using a Multisegment Model of The Foot and Ankle Complex. J Biomech Eng. 2009 Mar;131(3):034504. 
35. Leardini A, Benedetti MG, Berti L, Bettinelli D, Nativo R, Giannini S. Rear-foot, mid-foot and fore-foot motion during the stance phase of gait. Gait Posture. 2007 Mar;25(3):453-62.

36. Liacouras PC, Wayne JS. Computational Modeling to Predict Mechanical Function of Joints: Application to the Lower Leg With Simulation of Two Cadaver Studies. J Biomech Eng. 2007 Dec;129(6):811-17.

37. Salathe EP, Arangio GA. A Biomechanical Model of the Foot: The Role of Muscle, Tendons and Ligaments. J Biomech Eng. 2002 Jun;124(3):281-7.

38. MacWilliams BA, Cowley M, Nicholson DE. Foot kinematics and kinetics during adolescent gait. Gait Posture. 2003 Jun;17(3):214-24.

39. Scott SH, Winter DA. Biomechanical model of the human foot: Kinematics and kinetics during the stance phase of walking. J Biomech. 1933 Sep;26(9):1091-104.

40. Bruening DA, Cooney KM, Buczek FL. Analysis of a kinetic multi-segment foot model part II: kinetics and clinical implications. Gait Posture. 2012 Apr;35(4):535-40. 